\title{
A RELIGIÃO COMO FUNDAMENTO DA REFLEXÃO FILOSÓFICA E COMO MEIO DE AÇÃO POLÍTICA NAS LEIS DE PLATÃO
}

\author{
Luc Brisson*
}

RESUMO No décimo livro das Leis, Platão inaugura uma nova maneira de falar da divindade, mas of faz a contragosto e endereçando-se a uma minoria de indivíduos, a saber, jovens ateus que não foram convencidos pelos mitos que lhes foram contados desde a infância nem pelas práticas cultuais que testemunharam. Não podendo invocar a religião tradicional, Platão tenta dar uma demonstração da existência dos deuses, bem como de sua providência e incorruptibilidade, tomando por testemunho a regularidade e a permanência do movimento dos corpos celestes. Esse novo tipo de discurso sobre os deuses, que, mesmo se fundando sobre a religião tradicional, procura superá-la através da reflexão filosófica, é destinado a dar uma base ao governo da sociedade em seu conjunto.

Palavras-chave: Platão, Leis, mito, religião, demonstração da existência dos deuses

ABSTRACT In Book 10 of the Laws, Plato inaugurates a new way of speaking about the divinity, albeit reluctantly. He addresses a restricted group of individuals, young atheists who had not been convinced by the myths they had been told since childhood, or by the cult practices they had witnessed. Since he can no longer invoke traditional religion, Plato tries to give a demonstration of the existence of the gods, their providence, and their incor-

* "Directeur de recherches", CNRS, França. Texto recebido em abril e aprovado em maio de 2003. 
ruptibility, by calling on the regularity and the permanence of the motion of celestial bodies as his witnesses. This new kind of discourse on the gods, which, although based on traditional religion, seeks to transcend it by philosophical reflection, is intended to provide the foundation for the government of the whole of society.

Key words: Plato, Laws, myth, religion, demonstration of the existence of the gods

De uma maneira geral, pode-se dizer que a "teologia" é o estudo das questões relativas ao divino, estudo fundado na tradição e nos textos sagrados. A esse propósito, pode-se distinguir entre teologia especulativa e teologia positiva. A teologia especulativa é a sistematização racional dos dados fornecidos pela teologia positiva, a qual, na Grécia Antiga, onde a religião não estava fundada em nenhum texto sagrado e não dependia de nenhum clero permanente, confunde-se justamente com o conhecimento da tradição. Ora, em um contexto como o nosso de hoje, quando se usa o termo "teologia", pensa-se na teologia especulativa. É nesse sentido, em todo caso, que se tende a interpretar o procedimento de Platão no décimo livro das Leis. Eu gostaria de mostrar aqui que, no décimo livro, Platão inaugura uma nova maneira de falar da divindade, mas a contragosto e dirigindo-se a uma minoria de indivíduos, apesar de esse novo tipo de discurso sobre os deuses ser destinado a fundar o governo da sociedade em seu conjunto.

\section{Theología ou muthología}

Encontramos em Platão uma única aparição do termo theología, e essa aparição é ainda por cima discutível.

\section{SÓCRATES}

Adimanto, no presente momento nem eu nem você somos poetas (poietaí), mas fundadores (oikistaî) de cidades. Ora, a fundadores de cidade convém conhecer as formas (túpous) em que é preciso que os poetas fabriquem mitos (muthologeîn) e, quando estes os fabricarem, [fundadores de cidade] não devem conceder [que os poetas os fabriquem] não segundo essas formas —mas decerto eles não devem fabricar mitos. 


\section{ADIMANTO}

Tu dizes corretamente. Mas isso mesmo: quais seriam as formas a usar quando se fala de deuses (perì theologías) [ou quando se fabricam mitos (perì muthologías)]? (Resp. III 378e 4-379a 5)**.

Os manuscritos trazem theologías, mas o manuscrito T, uma cópia excelente do séc. XI e feita a partir do manuscrito A, o Parisinus 1807, ele mesmo copiado no final do séc. IX, traz a correção muthologías. Eu tenderia a aceitar tal correção, considerando o fato de que theologías é um hápax e que muthologías retoma o muthologeîn que se encontra acima, associado a túpous. De todo modo, ainda que não se aceite a correção, é preciso admitir que nessa passagem theologías é sinônimo de muthologías e que não corresponde de modo algum ao que encontramos em uma parte do décimo livro das Leis.

Para o Platão da República, o mito é o discurso pelo qual é comunicada toda informação sobre o passado longínquo que diz respeito aos deuses, aos demônios, aos habitantes do Hades, aos heróis e aos homens. Essa informação é conservada na memória de uma dada coletividade e transmitida oralmente de uma geração a outra, quer esse dicurso tenha sido elaborado por um técnico da comunicação coletiva do memorável (como o poeta) quer não.

De um extremo ao outro desse processo de comunicação, intervém a imitação. Esta está destinada a estabelecer uma fusão emocional que, manifestando-se na ocasião da fabricação e da interpretação do mito, faz intervir tanto a palavra quanto o gesto. Essa fusão dispõe aqueles que são seus destinatários a determinar ou modificar o próprio comportamento, físico e principalmente moral, em função do modelo que assim lhes é proposto.

Platão apresenta essa fusão emocional como o efeito de um encantamento ${ }^{1}$, que desempenha na alma o papel de um remédio ${ }^{2}$, de uma fascinação ${ }^{3}$ ou simplesmente de uma persuasão ${ }^{4}$, suscitados pelo prazer que a comunicação do mito proporciona à parte mais baixa da alma (a epithumía), a que deseja comida e bebida, a que é sede do apetite sexual ${ }^{5}$. Compreende-se, então, que os primeiros destinatários dos mitos são as crianças ${ }^{6}$. A infância e a juventude constituem, para Platão, a parte selvagem da existência huma-

\footnotetext{
** Todos os textos de Platão citados no presente artigo foram traduzidos diretamente do grego, mas levando em conta a interpretação do autor e com o seu aval [N.d.T.].

1 Leg. X 903a 7- b 3; Phaed. 114d 1-7; cf. 77d 5-78a 2.

2 Charm. 156d 3-157c 6.

3 Euthyd. 289e 1-290a 4.

4 Resp. III 415c 7; X 621c 1; Phaedr. 265b 8; Leg. VII 804e 5; X 887d 2; XI 913c 1-2; 927c 7-8.

5 Tim. 70d 7-e 5.

6 Resp. II 377b 6-7; Pol. 268e 4-5.
} 
$\mathrm{na}^{7}$, dado que, nessa idade, é a parte apetitiva que domina na alma ${ }^{8}$. E como o termo paidiá, 'brincadeira', deriva do termo paîs, 'criança', o mito vê-se muito naturalmente considerado por Platão como um brincadeira ${ }^{9}$.

\section{As relações ambíguas do lógos com o mûthos.}

Platão quer colocar o lógos no lugar do mûthos, mas deve levar em consideração o segundo para dar um fundamento ao primeiro e garantir sua eficácia.

A oposição mûthos / lógos pode ser interpretada não somente como a oposição discurso não verificável / discurso verificável, mas também como a oposição discurso narrativo (ou relato) / discurso argumentativo. Enquanto a primeira oposição está fundada em um critério externo - a relação do discurso com o referente ao qual ele supostamente remete-, o segundo depende de um critério interno - a organização de seu desenvolvimento. Há que notar que essa última oposição tem sentido apenas em um contexto filosófico, visto que a história, assim como o mito, deriva do relato.

Um relato narra acontecimentos como estes supostamente se produziram, sem propor explicação alguma: o encadeamento entre suas partes também é contingente, pelo menos em superfície, pois, especialmente desde V. Propp $^{10}$, várias tentativas foram feitas para destacar uma lógica do relato. De resto, o único objetivo de um relato, pelo menos aparentemente, é o de conseguir, por meio de quem o fabrica e/ou conta, fazer que o destinatário do relato modifique seu comportamento.

Em compensação, o discurso argumentativo segue uma ordem racional - seja qual for a definição da racionalidade acolhida. $\mathrm{O}$ encadeamento de suas partes dá-se, com base no modelo das matemáticas, segundo regras que têm por objetivo tornar necessária sua conclusão. E é um acordo racional acerca dessa conclusão o que é buscado por quem faz tal discurso.

No entanto, Platão não renuncia aos mitos tradicionais a que alude em sua obra ${ }^{11}$. Ele adapta mitos tradicionais e chega até mesmo a criar novos mitos em função das circunstâncias. E isso essencialmente por duas razões.

7 Leg. VIII 808c 7-809a 6.

8 Tim. 43a 6-44d 2.

9 Phaedr. 276e 1-3.

10 Vladmir Propp, Morphologie du conte [1928], seguido por Les Transformations des contes merveilleux [1925] com, em anexo L'étude structurale et typologique du conte [1969], par E. Mélétinski, traductions de Marguerite Derrida, Tzvetan Todorov e Claude Kahn, 'Point' 12, Paris, Le Seuil 1978. Cf. também as investigações de Claude Brémond em Logique du récit, Paris, Le Seuil 1978.

11 Para uma lista, cf. Anexo 3 de meu livro: Platon, les mots et les mythes [1982], 19942 p. 186-197. O fato de que Platão se limite a aludir a todas essas personagens prova a importância do mito em sua época. Quando um relato é realmente conhecido de todos, toda elaboração é supérflua. 
Por um lado, porque não se pode falar senão em termos míticos de um certo tipo de referentes, ou seja, de tudo o que diz respeito à alma e ao passado longínquo, e que, por isso, permanece inacessível tanto aos sentidos quanto à inteligência. A idéia de que a alma teve uma existência separada do corpo, durante a qual ela adquiriu um dado conhecimento que ela deve relembrar em suas existências ulteriores, está explicitamente relacionada com tradições religiosas no Ménon, no Fédon e no Banquete. A idéia segundo a qual seu comportamento anterior é objeto de uma retribuição está bem afirmada em vários mitos escatológicos. Enfim, a idéia segundo a qual ela se encarna em diversos corpos de seres humanos ou de animais está desenvolvida no Fedro e no Timeu. Ademais, tudo o que diz respeito ao inteligível está associado ao mito por meio dessas crenças sobre a alma. E é assim também no que diz respeito à fabricação do mundo sensível, como se pode constatar no Timeu. Por conseguinte, a mitologia constitui um terreno em que vários temas filosóficos afundam suas próprias raízes: é um reservatório de axiomas e de premissas.

\section{A eficácia do mito em ética e em política}

Platão reconhece, de resto, a eficácia do mito no âmbito da ética e da política, para a maioria dos que não são filósofos e nos quais predomina a parte desiderativa (epithumía) da alma. Na República, o mito da autoctonia, igualmente evocado nas Leis, e o dos metais servem a convencer os habitantes de que a cidade é una e indivisível, ainda que formada por grupos distintos. E nas Leis o mito desempenha um papel considerável no âmbito da legislação.

No livro IV das Leis (719c-724a) ${ }^{12}$ Platão interroga-se, com efeito, sobre a prática do legislador. Ele compara-o ao poeta e ao médico. Diferentemente do poeta, que não hesita em desenvolver sobre o mesmo assunto discursos que se contradizem ${ }^{13}$, o legislador é obrigado a fazer um discurso que não seja contraditório. Não obstante, mesmo se, sobre um mesmo e único assunto, ele faz um único discurso, ele não deve necessariamente limitar-se a fazer um discurso que seja simples.

Para ilustrar seu propósito, Platão evoca dois médicos ${ }^{14}$ cujos comporta-

12 Encontramos uma alusão clara a essa passagem no décimo livro das Leis (890c).

13 Essa é, aliás, a razão pela qual, como lembra Platão (Leg. IV 719b-c), o legislador não deve deixar ao poeta o direito de compor o que este quiser.

14 Platão parece aí referir-se a uma prática real. Na época clássica, os médicos eram assistidos por auxiliares, ajudantes (huperétal), aos quais ele dá o nome de 'médicos' também. A tal propósito, cf. F. Kudlien, Die Sklaven in der griechischen Medizin der klassichen und hellenistischen Zeit, Wiesbaden (F. Steiner) 1968, cap. 3; R. Joly, "Eclaves et médicins dans la Grèce", Sudhoffs Archiv für Geschichte der Medizin 
mentos diferem radicalmente. $\mathrm{O}$ primeiro não dá a seus doentes explicação alguma sobre o mal que os atinge e lhes prescreve brutalmente uma receita antes de deixá-los por um outro paciente. Já o segundo, ele informa-se junto ao doente e ao seu círculo e se concede o tempo de persuadir seu paciente do caráter fundamentado de suas prescrições ${ }^{15}$. Do mesmo modo, o discurso do legislador pode ser simples ou duplo. Se for simples, é curto e se compõe apenas de dois elementos: a prescrição da lei e a formulação das penas a que está sujeito quem não se submeter à lei. Ele é longo quando for duplo, e antepõe à prescrição da lei uma declaração que procura colocar a persuasão no lugar do medo do castigo, encontrado por quem não se conformar à lei. Desse modo, é a pesuasão que deve logo obter a obediência à lei.

Como lembra a passagem que segue, Platão tem consciência de inovar em matéria legislativa em relação aos códigos de leis gregos que chegaram até nós ${ }^{16}$, onde aparecem apenas o enunciado da lei e o inventário das penas infligidas em caso de contravenção.

Em relação a isso [i.e. a essa distinção], parece que, dentre os legisladores, nenhum já tenha pensado que, mesmo sendo permitido servir-se de dois [instrumentos] para legislar, persuasão e violência (peithoî kaì bía $(i))^{17}$, na medida em que, de resto, é possível [servir-se] disso para a massa cuja educação deixa a desejar (epì tòn ápeiron piadeías ókhlon $)^{18}$, servem-se apensas de um deles. Não legislam, com efeito, combinando a obrigação à persuasão (peithoî kerannúntes anágken), mas [servindo-se] apenas da força pura (akrátoi tê(i) bía(i)) (Leg. IV 722b-c).

und der Naturwissenschaften 53, 1969, p. 1-14. A asscociação da medicina à legislação volta com freqüência em Platão, desde a famosa passagem do Górgias (464b-465e) ou ainda da República (III 405a410b).

15 Sobre esse assunto, cf. Jacques Jouanna, "Le médicin, modèle du législateur dans les Lois de Platon", Ktèma 3, 1978, p. 77-92.

16 Tome-se como exemplo o código das leis de Gortina que é anterior ao séc. V: The law code of Gortyn, ed. with an introduction, translation and commentary by Ronald F. Willets, Berlin (de Gruyter) 1967. Há uma tradução francesa e um comentário desse código de leis em Nomina: recueil d'inscriptions politiques et juridiques de l'archaïsme grec, par Henri van Effenterre et Françoise Ruzé, École Française de Rome 188, Rome 1994-1995, 2 volumes.

17 Trata-se de um tema que remonta a Hesíodo.

18 Esta frase constitui um problema. A primeira dificuldade está na relação implicada pelo kath' hóson. A tradução que proponho aqui, e que vai na mesma direção da de L. Robin e de É. des Places, relaciona o inciso com peithoî kaì bía(i). Seguindo nisso E. B. England, Tr. Saunders parece relacioná-lo somente com a persuasão: "compulsion and persuasion (subject to the limitations imposed by the uneducated masses)". Mas, para chegar a tal, ele não respeita a ordem das palavras. A segunda dificuldade está na expressão epì tòn ápeiron paideías ókhlon. Como entender esse pedaço de frase, em se tratando da cidade dos Magnetos, onde a educação é obrigatória para todos os cidadãos? São possíveis duas respostas. A expressão epì tòn ápeiron paideías ókhlon indica ou que os preâmbulos dirigem-se aos cidadãos que não receberam educação superior (reservada, ao que parece, ao Colégio Noturno), ou que eles dirigem-se ao conjunto da população que compreende estrangeiros residentes e escravos, levando em conta, aliás, mulheres e crianças. Em ambos os casos, essa expressão constitui um golpe fatal para uma posição como a defendida nomeadamente por Chr. Bobonich e A. Laks. 
Para servir-se de persuasão, o texto da lei deve ser precedido por um preâmbulo (prooímion) ${ }^{19}$ que deve, antes de tudo, desempenhar o papel de uma exortação. Por meio de um jogo de palavras, Platão, com efeito, assimila a exortação (paramuthía ou paramuthíon) ${ }^{20}$ ao "mito que precede a lei (ho prò toû nómou mûthos)" "21. Nas Leis os preâmbulos são de três tipos. O primeiro grupo faz um uso sistemático das categorias retóricas do elogio e da reprovação, que recorrem a opiniões e a comportamentos normalmente partilhados pela maioria dos homens. O segundo grupo encontra sua principal reserva nos mitos. O terceiro implica a demonstração e é representado por um único caso: o livro $\mathrm{X}$ das Leis, que trata do ateísmo.

\section{Por que demonstrar a existência da divindade?}

Como ver o livro $\mathrm{X}$, que propõe uma demonstração da existência da divindade? Nenhuma legislação tem sentido se a ação humana não se desenvolve em um contexto social, político e, até mesmo e principalmente, cósmico, dotado de uma certa permanência e regularidade, que somente a divindade pode garantir. Disso se segue, para Platão, que impiedade e o não respeito da lei equivalem-se. A piedade favorece a obediência às leis, enquanto a impiedade questiona o próprio fundamento de toda lesgislação:

Nunca ninguém que ache, em conformidade com as leis, que os deuses existem cometeu voluntariamente um ato ímpio ou proferiu um discurso contra a lei. Mas [quem o faz fá-lo] decerto sob a ação de alguma destas três coisas: ou isso mesmo que eu disse, isto é, não achando [que os deuses existam]; ou, o segundo, [achando] que, mesmo existindo, [os deuses] não se preocupam com os homens; ou, terceiro, [achando] que [os deuses] são facilmente apaziguados e são seduzidos por meio de sacrifícios e preces (Leg. X 885b).

Aqui está a razão pela qual, no entender do Platão das Leis, uma lei

19 Como observa Jean-Marie Bertrand ("Formes du discours politique dans la cité des Magnètes platoniciens", Dike 1, 1998, p. 133, n. 82), 36 das 46 aparições desse termo encontram-se nas Leis: IV 722d 4, 7, e 2, 7, 723a 3, b 1, 5, c 2, 4, e 2, 6; V 734e 2, 4; VI 772e 4; IX 854a 3, c 6, 8, 870d 4, e 5, 880a 8; X 887a 3, c 1, 907d 1, 4; XI 916d 4, 923c 3, 925e 8, 930e 5, 932a 6. Sobre o sentido da palavra prooímion, ler M. Costantini e J. Lallot, "Le prooímion est-il un proème?", em Le texte et ses représentations, Études de littérature ancienne 3, Paris, PENS, 1987, p. 13-27. Segundo os autores, "o primeiro valor (desse termo) é o de 'hino preliminar' — sendo o referente por excelência o hino a uma divindade (cf. os Hinos Homéricos), recitado prò oímes, ou seja, antes dos poemas épicos, nos concursos de rapsodo. Daí derivam, por metáfora, tanto o uso no sentido amplo de 'prelúdio' (de poema) quanto o, mais especializado, de 'preâmbulo' (de lei) ou de 'exórdio' (de discurso)".

20 Nas Leis encontramos as seguintes aparições de paramuthía: IV 720a 1; de paramuthíon: Leg. I 632e 5; IV 704d 8, 705a 8; VI 773e 5; IX 880a 7; X 885b 3; XI 923c 2; de paramuthéomai: II 666a2; IX 854a 6; XI 928a 1; XII 944b 3. Há que observar também uma ocorrência do adjetivo verbal paramuthetéon em $X$ 899d 6 e do advérbio derivado aparamuthétos em V 731d 3. Para mais dados, cf. Luc Brisson, Platon, les mots et les mythes [1982], 19942, p. 195.

21 Leg. XI 927c. 
contra o ateísmo (907d-909d) deve necessariamente ser precedida por um preâmbulo, que contém quatro partes:

a) a primeira expõe as causas e as consequiências do ateísmo e da impiedade (885b-890b);

b) a segunda demonstra que os deuses existem (890b-899d);

c) a terceira explica que eles não se desinteressam das coisas humanas (899d905d);

d) a quarta adverte contra a crença segundo a qual podemos dobrá-los com preces e sacrifícios (905d-907d).

Platão parece pensar que a primeira demonstração concernente à existência dos deuses apresenta uma eficácia real, maior, em todo caso, que a concernente aos dois últimos casos de impiedade (888c-d).

Como fazer para trazer de volta para o bom caminho aqueles que acham ou que a divindade não existe ou que, se ela existe, não se ocupa das coisas humanas ou que ela se deixa dobrar ao sabor de nossas intervenções?

\section{O ateísmo}

No que diz respeito à existência dos deuses, Platão desenvolve uma demonstração (apódeixis 887a, 893b; epídeixis 892c, 899d) que introduz argumentos (lógois 887a). Trata-se não de uma escolha, e sim de uma necessidade, que se pode explicar muito facilmente. É preciso apresentar tal demonstração para aquele pequeno número de pessoas jovens nas quais a tradição não teve efeito e as quais não ficaram nem persuadidas pelos mitos nem impressionadas pelos ritos. É o que emerge claramente da seguinte passagem, particularmente interessante para um historiador da religião:

\section{O ESTRANGEIRO DE ATENAS}

Vamos lá. Como, sem cólera ${ }^{22}$, se pode dizer, a propósito dos deuses, que eles existem? Pois é certamente forçoso suportar com dificuldade e [887d] odiar aqueles que foram e são hoje $\mathrm{e}^{23}$ responsáveis por essas nossas demonstrações ${ }^{24}$, por não terem sido persuadidos pelos mitos ${ }^{25}$ que ouviram desde

22 O termo thumô(i) refere-se ao próthumos que está na frase anterior.

23 Os manuscritos trazem nun oun; nun ou é uma correção proposta por Estienne (Stephanus).

24 Dou um sentido forte a lógos em função do contexto e especialmente em virtude do que vem imediatamente depois.

25 Platão usa com muita freqüência o verbo peitheîn para descrever a ação exercida na alma pelo mito: Resp. III 415c; X 621c; Phaedr. 265b; Leg. VII 804e; X 887d; XI 913c, 927c. De fato, a persuasão dirigese às espécies mais baixas da alma, o desejo (epithumía) e a agressividade (thumós), e não ao intelecto (noûs). 
pequenos, quando ainda eram amamentados ${ }^{26}$, da boca das amas e das mães ${ }^{27}$, ouvindo-os como que em encantamentos ${ }^{28}$ por coisas pronunciadas tanto com seriedade $^{29}$ quanto por brincadeira e em preces que acompanham os sacrifícios, e vendo serem representados espetáculos, deles tirados ${ }^{30}$, de pessoas que sacrificam ${ }^{31}$ - [espetáculos] que um jovem vê e ouve com o maior pra$\mathrm{zer}^{32}$ - e [vendo] seus genitores empenharem-se, com a maior seriedade, em favor deles mesmos e dos seus, dirigindo-se com preces e súplicas a deuses, [887e] como se existissem o mais possível; enfim, vendo e ouvindo falar de genuflexões e prosternações, ao nascer e ao pôr do sol e da lua, por parte de todos os Gregos e de todos os bárbaros estando em todo tipo de desaventuras e na prosperidade, não achando que [o sol e a lua] não sejam deuses, mas que o sejam o mais possível ${ }^{33}$, e não deixando de modo algum suspeitar que não sejam deuses. A quantos - desprezando todos estes sem sequer uma única razão suficiente, como diriam todos os que têm um pouco de inteligênciahoje nos obrigam [888a] a demonstrar as coisas que demonstramos, como se poderia, ao admoestá-los, ensinar acerca dos deuses, em primeiro lugar, que eles existem? Mas há que ousar, pois decerto não é preciso que enlouqueçamos, uns por uma voracidade de prazer, outros por ficarem em cólera com tais pessoas. Seja dirigido, então, um tal discurso preliminar ${ }^{34}$ sem cólera àqueles assim corrompidos no pensamento, e falemos placidamente, apagando a cólera, como se conversássemos com um deles (Leg. 887d-888a).

Este texto é particularmente rico porque evoca não só os mitos mas também os ritos, porque fala não só das divindades do pántheon mas também desses deuses visíveis que são os astros e porque menciona não só os Gregos

26 Os destinatários privilegiados do mito são as crianças: Resp. II 377a, c; Pol. 268e; Soph. 242c; Tim. 23b; Leg. VIII 840c. Em Resp. II 377a precisa-se que se trata de crianças que ainda não vão ao ginásio.

27 As pessoas que contam os mitos de maneira não institucional são as mulheres que se ocupam das crianças, às quais os mitos são destinadas prioritariamente: a mãe (Resp. II 377c, 381e), a ama (Resp. II 377c), a velha (Gorg. 527a; Resp. I 350e), ou seja, a avó.

28 Esta passagem deve ser relacionada com Leg.II 659e. O encantamento é stricto sensu uma fórmula ritual pronunciada quando de uma cerimônia, que se trate de um sacrifício ou de um rito mistérico, e que supostamente possui um poder oculto, mas real. A ação exercida na alma pela comunicação de um mito está às vezes associada à fascinação mágica (kélesis) e ao encantamento (epo(i)dé) (Leg. II 659e, 903ab; Phaed. 114d, 77d-78a; Euthd. 289e).

29 A associação da brincadeira com a seriedade é freqüente quando Platão fala do mito: Leg. I 647d; II 659e; V 732d; VII 759d, 796d, 798b, 803c, d; XII 942a; Phlb. 30e; Resp. X 602b; Soph. 237b; Symp. 197e.

30 É esse o sentido que dou a kai ópseis horôntes hepoménas autoîs. Dou a ópsis o sentido de representação (espetáculo) e considero que autoîs substitui muthoîs.

31 Provavelmente, as partes do ritual que ilustram de um certo modo um episódio mítico. Poder-se-ia pensar também nas tragédias que ilustram mitos e que são precedidas por sacrifícios no qual tomam parte os vários participantes.

32 O prazer explica a eficácia do mito que, como eu disse, se dirige às espécies mais baixas da alma, cf. Tim. 26b-c; Phdo 110b; Prot. 320b-c.

33 A frase encontra-se mais acima.

34 Um equivalente de paramuthíon, logo de prooímion. 
mas também os bárbaros. E mais. Ele considera possível que a religião tradicional se mostre deficiente para garantir em todos a crença na existência dos deuses. Ora, essa não crença é capaz de acarretar duas conseqüências: a cólera naqueles que admitem a existência dos deuses, nomeadamente os legisladores, e uma busca desenfreada de prazer naqueles que se recusam a crer.

Daí vem a necessidade de uma lei muito severa contra o ateísmo (908e909d). Esta está precedida por um longo preâmbulo cujo objetivo é suprir as deficiências da tradição religiosa, incapaz de estabelecer a existência dos deuses. De fato, o conteúdo desse preâmbulo deve corresponder aos cursos dados por um ou mais de um membro do Conselho Noturno (nukterinòs súllogos) aos jovens condenados por impiedade e presos na "casa da volta à razão" (sophronistérion). Lembrar esse contex to de transmissão lança uma luz completamente diferente sobre o livro X das Leis.

\section{As causas do ateísmo}

Antes de apresentar duas provas (889b-c) em favor da existência dos deuses, uma prova cosmológica (893c-896e) e uma prova teleológica (896e897b), Platão começa interrogando-se sobre as fontes do ateísmo. Trata-se, segundo ele, de autores antigos que escreviam em versos e de autores modernos que escrevem em prosa.

Os antigos que escreviam em versos são evidentemente os poetas, considerados como os fabricantes de mitos ${ }^{35}$, atacados por Platão nos livros II e III da República:

Uns, os mais antigos ${ }^{36}$, dizem como nasceu a natureza ${ }^{37}$ primeira em relação ao céu ${ }^{38}$ e a todo o resto, mas, indo não muito adiante do princípio ${ }^{39}$, contam o nascimento dos deuses ${ }^{40}$ e como, uma vez nascidos, se relacionaram uns com os outros ${ }^{41}$. Não é fácil atribuir a [esses autores], que são antigos, as coisas que cabem aos que ouviram, ou seja, se, em relação a uma coisa ou outra, estão certas ou não $0^{42}$. Mas, por respeito e pelas honras devidos aos genitores ${ }^{43}$, eu certamente nunca diria, ao elogiá-los, que [esses rela-

35 L. Brisson, Platon, les mots et les mythes [1982], 19942, terceiro capítulo.

36 Ou seja, os poetas.

37 Acredito que se trate do Kháos, evocado na Teogonia de Hesíodo (v. 117) e mencionado no Banquete (178b). A Terra é mencionada ao mesmo tempo que o Kháos.

38 A Terra faz aparecer o Céu e de seus amplexos excessivos vem toda uma série de outras criaturas, entre as quais Cronos e Rea.

39 Em grego, arkhé.

40 Nomeadamente Cronos e Rea e depois, na geração seguinte, Zeus e Hera.

41 De modo muito violento, cf. Resp. II 377c s.

42 Uma observação que lembra Soph. 243a.

43 Cf. Resp. 378a. 
tos] são proveitosos, nem que disseram realmente tudo. Mas deixemos essas velharias e despeçamo-nos delas, e falemos, antes, do modo que aprouver aos deuses (Leg. X 886c-d).

Essa passagem reconhece a importância dos poetas, como fabricantes de mitos, em matéria de religião. Mas esse reconhecimento, que equivale a admitir que o procedimento filosófico está arraigado no mito, é crítico, já que os poetas nem sempre dizem bem o que se deve dizer. Não se pode dizer que Platão aqui seja menos radical em sua crítica da poesia do que quanto tenha sido na República, ainda que mostre, em relação aos mitos, um certo pudor, que ele justifica pelo respeito devido aos que nos engendraram; a expressão é ambígua, pois pode tratar-se dos deuses, que são nossos genitores longínquos, ou de nossos pais, que são nossos genitores próximos. Eu estaria mais propenso para essa segunda hipótese, embora a primeira também deva ser levada em consideração. Recusar brutalmente os mitos a que nossos pais davam crédito, é, de uma maneira ou de outra, questionar a sua autoridade. No entanto, não mais do que na República, nas Leis Platão tampouco aceita que os poetas privem os deuses destas duas características: a bondade e a perfeição. A idéia é sempre a mesma. Podemos servir-nos dos mitos, mas desde que eles sejam conformes a uma certa representação da divindade, da qual os filósofos são fiadores.

Mas há outros promotores do ateísmo: são os sábios modernos, que escrevem em prosa. Há que reconhecer neles tanto os que investigam sobre a natureza, os "fisiólogos" ${ }^{4}$, quanto os sofistas que retomaram um certo número de doutrinas daqueles.

Todavia, sejam denunciadas as coisas que nos dizem os modernos e sábios pelos males de que são responsáveis. Os discursos de tais pessoas produzem o seguinte: quando, com efeito, dermos provas de que são deuses meus e seus, apresentando essas próprias coisas —o sol, a lua, os astros e a terra- como se fossem deuses e coisas divinas, podem dizer, persuadidos por esses sábios, que são terra e pedras e não são absolutamente capazes de se preocupar com as coisas humanas, sendo elas mais ou menos bem espalhadas por aí com discursos para serem algo de crível (Leg. X 886d-e).

Esses modernos que são sábios destruíram a crença natural na existência dos deuses que os mitos, bem ou mal, haviam enraizado no coração de todos os cidadãos.

O axioma em que o ateísmo desses sábios mergulha as próprias raízes consiste nestas poucas palavras: "Parece, dizem, que natureza e acaso produzam as coisas maiores e mais belas, enquanto a técnica produz as menores. 
Esta, tomando da natureza a geração de todos os grandes e primeiros produtos, plasma e fabrica todos os pequenos, os que todos chamamos artificiais" (Leg. X 889a). Isso implica que a realidade em seu conjunto resulta exclusivamente ou da ação da natureza assimilada ao acaso, ou da técnica, logo da convenção (Leg. X 886d-e, 889b-c).

Desse axioma decorrem dois tipos de conseqüências: umas interessam a física, as outras, a ética ${ }^{45}$. É preciso admitir, com efeito, que os deuses e os valores são sub-produtos da arte, a qual, por sua vez, é um produto da natureza.

Estes dizem que são primeiramente os deuses a ser por técnica, ou seja, não por natureza, mas por certas leis; que eles são uns aqui outros lá, conforme que [os homens] de cada [lugar], ao estabelecer as leis, tenham concordado entre si; e que as coisas belas por natureza são decerto diversas das que o são por lei. [Dizem que] tampouco as coisas justas são tais totalmente por natureza, mas que [os homens] passam a vida toda disputando entre si [sobre elas] e mudando-as continuamente. E, mesmo que as mudem, cada uma delas é ainda dominante, visto que são engendradas por técnica e pelas leis, e não decerto por alguma natureza (Leg. X 889e-890a).

A técnica (tékhne), que é o último produto da natureza (phúsis) e do acaso (túkhe), encontra-se aqui, no que diz respeito aos deuses e aos valores, assimilada à lei. Tal concepção cria a possibilidade de um conflito entre a natureza e a lei, que se encontra do lado da técnica, pois certos valores são atribuídos à natureza e outros, à lei. No entanto, enquanto a natureza é a mesma em toda parte, as leis que resultam da técnica diferem conforme as legislações. Por conseguinte, os valores são convencionais e, assim, mutáveis, já que, tendo eles uma origem, terão um fim. O legislador e os dirigentes da cidade não podem pretender possuir uma arte verdadeira, de origem divina. Como, então, os cidadãos poderiam sentir-se obrigados por essas leis? Nesse contexto, todo projeto de legislação fundado no reconhecimento de valores indiscutíveis e, por conseguinte, universais deve ser abandonado logo de saída.

\section{As provas da existência da divindade}

Para evitar esse desastre, Platão deve provar que a divindade não é questão de convenção. Para tal, ele desenvolve uma prova de que o movimento ordenado do mundo é obra de uma alma dotada de razão.

45 Para uma descrição completa, cf. Wauthier de Mahieu, "La doctrine des athées dans le Xe livre des Lois",

Revue Belge de Philologie et d'Histoire 41, 1963, p. 5-24; 42, 1964, p. 16-47. Ver também Luc Brisson, Le même et l'autre dans la structure ontologique du Timée de Platon [1974], 19983, p. 504-508. 
Tudo o que se move é posto em movimento por um outro ser. Ora, é preciso que haja um ser que possa pôr em movimento a si mesmo sem ter sido posto em movimento por um outro, sob pena de proceder ao infinito. Esse ser é precisamente a alma, princípio auto-motor de todo movimento. Enquanto os ateus acreditam que a causa do movimento se encontre nos quatro elementos, Platão julga que ela resida na alma. Assim, demonstrando a anterioridade da alma em relação ao corpo, estabelecemos que a alma é justamente a causa primeira buscada, pelo menos no universo.

Mas esse primeiro argumento não é suficiente. A alma não é, com efeito, o princípio supremo a que Platão visa, quando ele pensa na divindade. A alma é neutra e, por conseguinte, ela pode ser boa ou má, conforme as circunstâncias, enquanto a divindade deve por definição (cf. Resp. II e III) ser boa em todas as circunstâncias. Desse modo, é preciso determinar qual faculdade garantirá, de maneira permanente, a bondade à alma. Essa faculdade é o intelecto (nô̂s) que, na ordem da natureza, a do mundo visível, se manifesta pela harmonia que ela instaura e mantém. É por isso que, após uma importante transição (896e-897b), um outro argumento é desenvolvido, o "argumento teleológico" (897b-899b).

Lembremos uma vez mais a questão posta no início. O céu e tudo o que ele contém são governados pela alma melhor ou pelo seu contrário? Para responder a tal pergunta, Platão mostrou primeiro que os movimentos dos corpos celestes eram da mesma natureza que os do intelecto, que é, ele mesmo, divino. Em seguida, ele explicou que os movimentos do céu e os do intelecto eram ambos comparáveis aos de uma esfera arredondada em volta, a figura mais perfeita a seus olhos, e que eles descreviam rotações circulares. Pode-se concluir, então, que a alma que provê para que o céu se mova circularmente, de maneira sempre idêntica e ordenada (899c), é a melhor.

Aqui está um inventário das teses que aparecem nessa argumentação, seguindo a ordem de apresentação:

- a alma anima todas as coisas;

— logo os corpos celestes são necessariamente animados por uma alma;

- a alma pode unir-se ao intelecto, que é divino;

- os movimentos do intelecto são circulares;

—os movimentos dos astros são circulares, logo divinos.

A simples observação dos astros deveria, nessas condições, ser suficiente para convencer de que os movimentos do céu e os do intelecto são idênticos e que, por conseguinte, é a alma melhor que cuida de tudo. Não obstante, a coisa é mais complicada. A observação do céu revela, com efeito, que os 
movimentos de certos astros parecem ser não regulares e sim errantes. Ora, somente o recurso à astronomia matemática pode mostrar que esses astros, até então considerados errantes, movem-se circularmente ou racionalmente, o que dá no mesmo.

\section{$O$ contexto da prova}

Essa demonstração deve ser feita aos ateus em uma prisão que fica nos próprios lugares em que se reúne o Conselho Noturno (nukterinòs súllogos). Não se sabe onde fisicamente se encontra o lugar onde se reúne o Conselho Noturno. Mas se conhece seu nome. Trata-se da "Casa da Volta à Razão" $(\text { sophronistérion })^{46}$, uma das três prisões que a cidade possui. Essa prisão $0^{47}$ é reservada aos ateus que se acredita serem recuperáveis. Dentre as três espécies de ateus evocadas acima —os que não admitem a existência dos deuses, os que julgam que eles não se ocupam das coisas humanas e os que acreditam que eles podem ser influenciados- Platão distingue dois grupos: os que têm "um caráter naturalmente justo" (Leg. X 908b) e os que demonstram "incontinência em relação tanto aos prazeres quanto às dores" (Leg. X 908c). Os segundos são irrecuperáveis e devem ser executados, enquanto os primeiros devem ser submetidos a admoestação (nouthétesis) e à prisão (desmós) (Leg. X 908e). E Platão continua do seguinte modo:

Uma vez feitas essas distinções desse modo, que o juiz (ho dikastés) competente mande, em virtude da lei (nómo(i)), os que se tornaram assim sob o efeito da falta de inteligência (hup' anoías) sem maldade de temperamento ou caráter (áneu kákes orgés te kaì éthous) à "Casa da Volta à Razão" (sophronistérion) por um período não inferior a cinco anos e que durante esse tempo nenhum cidadão se encontre com eles, exceto os integrantes do Conselho Noturno (nukterinòs súllogos), que os encontrarão para uma admoestação (epì nouthetései) e para a salvação da alma (kaì tê(i) tês psukhês sotería(i)). Uma vez completado o tempo de prisão, se algum deles parecer ter voltado à razão (sophroneîn), que conviva com as pessoas razoáveis (metà tôn sophro-

46 Esse termo é usado apenas duas vezes por Platão, e precisamente nessa passagem. O termo associa dois diferentes sufixos: um em -tér, que indica um nome de ação, e o outro, no neutro, -ion, que indica um lugar. O termo sophronistér é o nome que os Tebanos deram à pedra (Pausânias IX 11, 2) que Atená lançou sobre Héracles, o qual queria matar Amfítrion. Essa pedra que fez Héracles por um momento cair em inconsciência reconduziu-o à razão, ao impedir que cometesse o assassinato que ele estava para cometer. Pode-se também aproximar o termo sophronistér de sophronistés, que designa, segundo Aristóteles, subalternos do Cosmeta: eles são eleitos, um por cada tribo, não pelo Areópago, mas por uma assembléia de pais de família (Ath. resp. XLII 2; mencionado em Ax. 367a; cf. também Resp. 471a)

47 Observe-se que esse tipo de estabelecimento é muito diferente da prisão (desmotérion) que, em Atenas, era um lugar em que ficava guardado alguém à espera do pagamento de uma multa a que fora condenado ou à espera da própria execução, como foi o caso de Sócrates. Sobre o assunto, cf. S. C. Todd, The shape of Athenian law, Oxford (Clarendon Press) 1993, p. 139-140. 
nôn), se não, e caso sofra de novo tal condenação, que seja punido com a morte (Leg. X 909a).

Segundo as informações dadas no livro $\mathrm{X}$ das Leis, uma das tarefas do Conselho Noturno é a de combater a impiedade sob todas as suas formas e garantir a salvação da alma dos cidadãos. Em ambos os casos, a preocupação do Conselho Noturno tem por objeto a alma, a do ser humano, que deve ser preservada do ateísmo, e até mesmo a do universo, que deve ser compreendida e descrita graças ao estudo da astronomia.

\section{A utilidade dessa prova}

O recurso à astronomia pode parecer insólito a um contemporâneo, mas apresenta várias vantagens aos olhos de Platão. Enquanto os mitos evocados em um certo número de preâmbulos mencionam divindades tradicionais invisíveis, que não se manifestam senão em circunstâncias particulares, a observação do movimento dos corpos celestes é possível quase todos os dias por todos os homens. Ao cidadão das Leis basta, então, levantar a cabeça para se convencer da existência dos deuses e para ser persuadido de que o mundo não está abandonado ao acaso e que o estabelecimento de leis permite, na sociedade, o advento de uma ordem que reproduz a que se manifesta no universo e principalmente no céu.

Relacionando a ética e a política com a cosmologia, Platão não dá mostra de modernidade. Max Weber, que analisa a modernidade em termos de racionalização, julga que essa racionalização, que diz respeito aos problemas técnicos, tem por primeiro efeito a dissociação das diferentes esferas de pensamento e de atividade, que se tornam autônomas umas em relação às outras, na medida em que elas obedecem a um conjunto de regras e de procedimentos próprios, sendo a Administração o exemplo mais flagrante disso em nossas sociedades. A tal propósito, pode ser interessante notar que, nas Leis, os membros do Conselho Noturno definem os objetivos da cidade e controlam sua ação sem apoiar-se em uma Administração. A eles basta contemplar o universo para saber a que ater-se e o que fazer. É esse saber que, em última análise, justifica sua função de dirigentes.

Mas o que o pensamento de Platão apresenta de insólito a nossos olhos inversamente destaca, ao mesmo tempo, a originalidade e, assim, o caráter arbitrário que marcam a orientação geral dos sistemas éticos e políticos de que hoje em dia continuamos a ser, de um modo ou de outro, tributários. 